\title{
Lakes, presidents and shopping on mental maps: children's perceptions of the Finnish-Russian border and the borderland
}

\author{
VIRPI KAISTO AND OLGA BREDNIKOVA
}

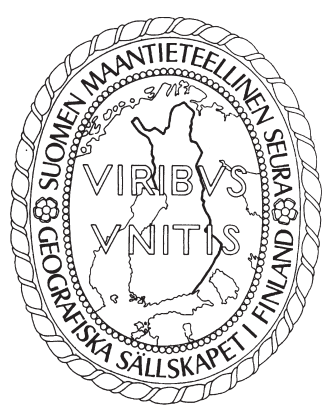

Kaisto, V. \& Brednikova, O. (2019) Lakes, presidents and shopping on mental maps: children's perceptions of the Finnish-Russian border and the borderland. Fennia 197(1) 58-76. https://doi.org/10.11143/fennia.73208

$\mathbf{y}$ The Finnish-Russian borderland has transformed in the last three decades from two isolated national territories into a transition zone, where the 'other' culture and society is ever more present. This paper analyses what kinds of perceptions Finnish and Russian children have of the border and the borderland today. It also examines children's territorial identifications in the borderland. The research is based on 263 mental maps collected from 9-15-year-old children in the cities of Lappeenranta (Finland) and Vyborg (Russia) and the village of Pervomayskoe (Russia) between 2013 and 2017. The analysis of the maps illustrates that the children participating in the study perceive the Finnish-Russian border mainly as a place for border crossings, although they continue to use the border as a tool for constructing sociospatial distinctions. In this way, the children actively participate in processes of bordering and play an important part in the social life of the borderland. The participants' perceptions of the borderland are connected to the national and local contexts that they live in but vary widely between individuals. The paper argues that the local border-related phenomena and children's border-crossing experiences are increasingly relevant for their national and local identification processes. Besides providing novel information regarding Finnish and Russian children's perceptions and identifications in the Finnish-Russian borderland, the paper adjusts the mental mapping method to a borderland context and enhances our understanding of the complexity of the bordering processes taking place in borderlands.

Keywords: mental mapping, children, perception, Finnish-Russian border, borderland, territorial identification

Virpi Kaisto, Karelian Institute, University of Eastern Finland, P.O. Box 111, 80101 Joensuu, Finland. E-mail: virpi.kaisto@uef.fi

Olga Brednikova, Centre for Independent Social Research, Office 301, Ligovsky prospekt 87, P.O. Box 193, 191040 St. Petersburg, Russia. E-mail: brednikova@cisr.ru

\section{Introduction}

Currently, scholars studying borders and borderlands approach borders as 'borderings' rather than as mere physical markers of territorial divisions (e.g. Popescu 2012; McKnight \& Leonard 2014; Scott 2015; Scott \& Sohn 2018). Scott $(2015,27-28)$ defines bordering as 'everyday construction of borders

URN:NBN:fi:tsv-oa73208

DOI: 10.11143/fennia.73208 (cc) BY (c) 2019 by the author. This open access article is licensed under a Creative Commons Attribution 4.0 International License. 
among communities and groups through ideology, discourses, political institutions, attitudes and agency'. Bordering builds on the constructivist view of social reality, which holds that borders are social constructs that are produced by people in their everyday lives (Newman 2003; van Houtum et al. 2005). When studying borders as borderings, one needs to ask the crucial questions of 'Who borders?' and 'Who participates in bordering processes?'. Spyrou and Christou (2014) argue that border studies have failed to recognise the role of children as active participants in borderlands and bordering processes. According to them, borders and borderlands are not only an outcome of adult activity but also of children. This argument aligns with current childhood research, which considers children active agents in their everyday lives and in the larger social fabric (Qvortrup et al. 2016). Thus, when borders are approached as bordering processes and social constructs, children are not mere objects of the institutional or mental power that borders have over them; rather, they are active participants in (de)constructing borders (Spyrou \& Christou 2014).

This paper studies children ${ }^{1}$ living in the Finnish-Russian borderland, with the aim to analyse what kinds of perceptions Finnish and Russian children have of the Finnish-Russian border and the borderland. The paper also examines children's territorial identifications in the borderland. The Finnish-Russian borderland provides an intriguing context for studying borders and bordering processes due to its history and the changing meanings attached to the border in Finland and Russia. As a result of the Second World War, the Finnish-Russian border was moved westward and almost entirely closed off to travelling and interaction. Since the collapse of the Soviet Union in 1991, five new international border crossing points have been opened, and the number of travellers crossing the border has increased from approximately 4 million (1997) to around 10 million a year (fluctuating annually depending on the economic and political situation). The growing number of travellers has induced investments in the border regions and shops, and leisure facilities and other services have been opened to serve the visitors, especially on the Finnish side of the border. The number of migrants from Russia to Finland's border municipalities has also increased substantially. As a result of the cross-border flows, the Finnish-Russian borderland is transforming from an alienated to an interdependent borderland (see Martinez 1994), that is, from two isolated national territories into a transition zone, where the 'other' culture and society is ever more present. Consequently, the meanings of the border and the representations held of it in Finland and Russia have become more varied. While for most of the Soviet period the border represented a closed ideological border between East and West, it has since become a topic in economic, political, military and cultural discourses (Paasi 1996).

Thus, today's children live in a very different Finnish-Russian borderland compared to that of their parents or grandparents. Moreover, it is not only the borderland around them that is transforming. Due to globalisation, increasing mobility, the Internet and technological development, the social reality is also changing. Childhood and youth researchers have pointed out that Internet and social media and the opportunities provided by these tools encourage a more fluid, creative and autonomous youth, which does not bend to traditional class-based (or other) classifications (Cieslik \& Simpson 2013). However, children and young people cannot entirely disengage themselves from contested memories, histories, cultures and practices (McKnight \& Leonard 2014), even though growing up in a period of more open borders affords them new possibilities of thinking and negotiating collective images and stereotypes.

In this context, it becomes intriguing to observe the images that children today have of the FinnishRussian border and the borderland. Despite the vast amount of literature scrutinising the FinnishRussian border, the viewpoint of children and young people has remained almost unstudied. To the best of our knowledge, Jukarainen (2001) has been the only researcher to explore young people's perceptions of the border areas between Finland and Russia. Jukarainen showed how the national framework was the dominant one for young people and how Finnish young people were inclined to perceive the Finnish-Russian border as a cultural barrier, viewing the Russian side as strange or frightening. Meanwhile, Russian young people recognised the existence of a cultural boundary but saw the physical border as an opportunity for exploring the other side. However, almost two decades have passed since Jukarainen's study, and the changes in the social context have most likely had an influence on children's and young people's perceptions and identifications. 
We applied the mental mapping methodology to analyse these perceptions and identifications. Between 2013 and 2017, we collected 263 mental maps from schoolchildren in two cities (Lappeenranta, Finland and Vyborg, Russia) and one village (Pervomayskoe, Russia) in the Finnish-Russian borderland. Based on the findings of the analysis, we argue that local border-related phenomena and children's border-crossing experiences are increasingly relevant for their national and local identification processes. This paper begins by discussing borderlands as distinctive localities for children to experience and live in. We then introduce spatial socialisation as a concept addressing the development of territorial belonging. In the next chapter, we focus on the mental mapping method and show how we applied it to a borderland context. We continue with a discussion about the findings of the analysis of the mental maps and conclude with contributions and ideas for further research.

\section{Children experiencing and constructing borderlands}

Since the late 1990s, border scholars have come to approach state borders as more than territorially fixed static lines - they are an inseparable part of people's spatio-temporal activities and mindscapes (Paasi 1996; Prokkola 2008) and are socially constructed through ideology, discourses, political institutions, attitudes and agency (Scott 2015). Thus, borders are 'borderings' that people use for ordering space (constructing socio-spatial distinctions) and negotiating their identities (van Houtum et al. 2005; Scott \& Sohn 2018).

Although, following this realisation, the study of borders has moved partly away from actual borderlines into societies at large (Rumford 2008), borderlands preserve their salience as research sites for exploring the processes of bordering and the construction of national and other collective identities (Popescu 2012). This follows from the characteristics of borderlands as transition zones between two national territories. Depending of the openness of the border, borderlands, as areas situated near state borders, are exposed to varying degrees of transnational flows and processes (Martinez 1994; Newman 2003). These challenge the role that borders play as markers of national identity and affiliation, that is, as boundaries between 'us' and 'them' (Paasi 1996; Prokkola 2008). In borderlands, inhabitants are exposed to 'foreign values, ideas, customs, traditions, institutions, tastes, and behaviour' (Martinez 1994, 10) because the 'other' culture and society is constantly present. Hence, borderland inhabitants are more likely to negotiate their national and other collective belongings in their everyday lives than are people living in more central parts of states.

Studies from different borderlands have demonstrated that, on the one hand, national borders and the national context continue to serve as most people's most important identity framework (Popescu 2012; Wilson \& Donnan 2012). Even in EU internal border regions, where border controls have been demolished, borders remain real in people's minds, and their everyday practices and routines often remain bordered and nationalised (Strüver 2005). On the other hand, research shows that, in practice, borderland inhabitants are affected by the border and identify with it in varying ways and degrees; at one extreme are people who are largely unaffected by the border, and at the other are people whose ways of life are strongly characterised by it (Martinez 1994; Paasi 1996; Prokkola 2008).

To date, relatively little research has been carried out about children living in different borderlands of the world. The existing studies highlight both the institutional power that borders have over children and their active role in borderlands and bordering processes (Spyrou \& Christou 2014). For instance, Venken (2017) notes that borderland children of the First and Second World Wars were subjects of nationalist policies but were often engaged in non-national practices that contributed to a more stable and peaceful Europe. Spyrou and Christou (2014) show that the Green Line separating the northern and southern areas of Cyprus is central for Creek and Turkish Cypriot children in terms of defining the 'self' and the 'other'. Existing research also indicates that for children, borderlands can function as 'incubators of multiple identities and senses of belonging', and borders can become a central feature of their geographical identity (Spyrou \& Christou 2014). In her study on young people in the Portuguese-Spanish borderland, da Silva (2014) shows that the border can lose its meaning as a symbolic and physical separation when the 'other side' of the borderland is integrated into the lives of children and young people through everyday practices in childhood and youth. These examples 
suggest that children's relationship with borders and borderlands depends largely on the spatial and social context that they live in.

In contrast to borderlands, the local context has received considerable attention in geographical research on children (Holloway \& Valentine 2004). This has been motivated by the fact that children are often more limited in their mobility than adults and spend more time in local places and communities. The experiences of children in localities also differ from those of adults, among other reasons, due to their mediated nature (Scourfield et al. 2006). Research on children in different localities has been informed by a current understanding that places and spaces are dynamic and socially constructed: they are imbued with meaning, symbolism and emotions, and they are not mere containers of physical objects and people (Gieseking et al. 2014). People's relationships with places are complex, as they are shaped both by the feelings and meanings that individuals themselves attach to places and by the larger social context of which an individual is part. In terms of identity (understood as 'how we make sense of ourselves'), a place and meanings given to a place may become a central part of the identity of the people experiencing them (Rose 1995). Research on children's territorial identities has shown that local place identities are deeply interconnected with national identity, as one's national belonging is tied with how one perceives - and how others perceive - the place in which one lives (Scourfield et al. 2006).

\section{Development of territorial belonging through spatial socialisation}

It is well recognised that spatial and social contexts affect children's self-identity and worldviews. These, on the other hand, have a strong influence on how children see themselves regarding others and what they base their actions on, including where they choose to study, work, travel and who they choose to socialise with (White \& Green 2012; Rinne \& Kallio 2017). As mentioned above, it is the intermingling of the national and local frameworks that turns borderlands into distinctive contexts for children to grow up and live in.

Different theoretical approaches exist in the literature regarding how a person identifies with a nation (e.g. Anderson 1983; Billig 1995), but few of them take children seriously (Scourfield et al. 2006). This is surprising, considering that a person's identification with a nation begins to take root in childhood (ibid.). Our knowledge, beliefs and feelings about different nations and national groups develop through the course of childhood and early adolescence and are never stable (Barrett 2007). Debates continue over how national feeling arises in childhood and whether it occurs more through top-down socialisation (formal schooling and media discourse backed up by adults familiar with national iconography) or through informal ethnic or cultural practices and routines (Scourfield et al. 2006; Barrett 2007; Habashi \& Worley 2009).

One of the theories addressing this question, and the one that we find extremely useful in analysing the mental maps of the Finnish and Russian children, is Paasi's (1996) concept of 'spatial socialisation'. This refers to the process of socialisation of an individual to a territorially bounded spatial entity (such as a state) by means of internalising collective territorial identities and shared traditions. For many people, the most powerful scale of spatial socialisation is the national scale, in reference to which Paasi talks about 'national socialisation'. We become identified with the state through institutional and mundane practices that include, among other things, governance, politics, education, media, literature and various places of memory (such as memorials and museums) (ibid.; Habashi \& Worley 2009). Nevertheless, the state is not the only identity framework. Indeed, people identify themselves with several territorial communities at the same time (Paasi 1996). From this perspective, borderlands are places where people from different national identity frameworks encounter each other, but which (with their border-crossing characteristics) can also function as identity contexts for people.

Kallio $(2014,211)$ has applied the concept of spatial socialisation to childhood studies and put forward an approach that considers spatial socialisation as 'a dynamic and relational process of political becoming'. By this, she refers to new social studies of childhood in which children are understood as active and capable agents who take part in peer and multigenerational communities from very early on (see Holloway \& Valentine 2004). Socialisation processes occur in socio-spatial contexts, such as family, friends, neighbourhood, school and other social institutions (Kallio 2014). In 
these processes, children are not mere objects but rather active participants, even though in comparison to adults their socialisation is more effectual and open-ended. What is central for Kallio's understanding is the relational approach to space because it explains how the processes of spatial socialisation produce 'related yet unique people'. Children growing up in the same community often share the same education, institutional practices and media coverage, but they do not turn into identical like-minded subjects. Following this line of thinking, we can examine the mental maps of this study both as collective and individual representations. We can also approach the children taking part in the study as competent agents in their communities who (re)produce the political realities that they share (see Kallio 2014).

\section{The mental mapping method in a borderland context}

Mental maps are hand-drawn visual representations of a particular place or space. In the process of mental mapping, a person draws a tangible version of his or her 'map in the mind', which includes the information, emotions and ideas that he or she holds of a certain place or space, whether these are real and/or imagined (Gieseking 2013). The mental mapping methodology was originally developed in the 1950s and 1960s. One of the pioneering figures of mental mapping was Lynch (1960), who collected sketch maps from city dwellers to understand their mental picture of the exterior physical world and to thereby assist urban planners in their work (Gieseking et al. 2014). Many early mental mapping studies focused on children and young people, examining their spatial cognition and mapping abilities (Hart \& Moore 1973; Stea \& Blaut 1973), and the knowledge and representations that they hold of the world and different countries and states (Gould 1973; Saarinen 1973; Gould \& White 1974). These studies showed that a person's spatial cognition develops with age, and that the way children and young people relate to different places depends on where they live and their social and cultural (ethnic, religious etc.) background. More recent mental mapping research with children and young people has confirmed that a person's national and cultural background has a strong influence on how he or she perceives a certain place or area (Gillespie 2010; Reynolds \& Vinterek 2016). Thus, rather than being reflections of the natural environment, mental maps reflect our collective identities and can therefore be analysed both as individual representations and as mirrors of collective worldviews.

As a rule, mental maps are created on a blank sheet of paper, and people are asked to draw what they know, believe or feel about a certain place or space, for instance, their neighbourhood, city or the world (Gieseking 2013). Our task was to develop a method that would be suitable for children and for a borderland context. To the best of our knowledge, only Scholz (2011) has applied the mental mapping method to a borderland context to study young people's perceptions of the Euroregion of Saar-LorLux. She asked young people aged 14 to 17 years to draw their region as they live and experience it on a blank paper. She discovered that the young people had a lot of experience visiting the neighbouring regions, and they used borders together with several other elements (place names, attractions, culinary treats etc.) as an important means for ordering and structuring the cross-border space.

Our initial intention was also to use the blank paper approach, but after piloting the exercise with both a blank paper and an existing map with the outlines of borders and water basins, we chose to develop a simple base map for our study. ${ }^{2}$ We left a lot of free space on the base map for the participants to draw and write on, and the Finnish-Russian borderline running in the middle of it and a thumbnail picture of the area in the upper left corner helped the participants to orient themselves and get started with the exercise. The most substantial disadvantage of the base map was that it introduced the Finnish-Russian borderline for the participants and thereby 'presupposed' that the border exists in their minds. Most likely, the border encouraged the participants to make comparisons between the Finnish and Russian sides, which is both a weakness and strength of the study. We are not able to see how the participants would have drawn the borderland and whether the border would have been present on the maps. On the other hand, the comparisons that the participants made form a rich image of how they perceive their side and the other side of the border.

The 263 mental maps that serve as the research material of this paper were collected in the cities of Lappeenranta (Finland) and Vyborg (Russia) as well as the village of Pervomayskoe in 2013, 2014, 
Table 1. The mental maps by year, country, school, class and number.

\begin{tabular}{|c|c|c|c|c|}
\hline Year & Country & School & Class & Number of maps \\
\hline \multirow{4}{*}{2013} & \multirow{3}{*}{ Finland } & \multirow{2}{*}{ School 1} & 4 & 24 \\
\hline & & & 9 & 31 \\
\hline & & School 2 & 9 & 20 \\
\hline & Russia & School 5 & 9 & 7 \\
\hline \multirow{2}{*}{2014} & \multirow{2}{*}{ Russia } & \multirow{2}{*}{ School 4} & 5 & 15 \\
\hline & & & 8 & 16 \\
\hline \multirow{4}{*}{2016} & \multirow{4}{*}{ Finland } & \multirow{2}{*}{ School 1} & 5 & 21 \\
\hline & & & 8 & 23 \\
\hline & & School 2 & 5 & 21 \\
\hline & & School 3 & 8 & 17 \\
\hline \multirow{3}{*}{2017} & \multirow{3}{*}{ Russia } & \multirow{3}{*}{ School 5} & 4 & 32 \\
\hline & & & 8 & 25 \\
\hline & & & 9 & 11 \\
\hline \multirow{3}{*}{ Total } & Finland & 3 & 7 & 157 \\
\hline & Russia & 2 & 6 & 106 \\
\hline & Total & 5 & 13 & 263 \\
\hline
\end{tabular}

2016 and $2017 .{ }^{3}$ Lappeenranta and Vyborg are located a similar distance (approximately 30 kilometres) from the Finnish-Russian border and are the largest cities of their respective administrative regions. In 2016, there were 73,000 inhabitants in Lappeenranta and 79,000 inhabitants in Vyborg. The second busiest border crossing point along the Finnish-Russian border, Nuijamaa/Brusnichnoe, is located between the cities, and both cities are popular cross-border tourist and shopping destinations. Pervomayskoe, on the other hand, is a village situated between the cities of Vyborg and St Petersburg, 110 kilometres from the Finnish-Russian border. With its 4,500 inhabitants (2016), it is the administrative centre of the rural settlement of Pervomayskoe, one of the 14 settlements of the Vyborg region. Having Pervomayskoe as one of the locations allowed us to study whether the greater distance to the border would influence the children's perceptions.

The mental maps of this study are from three schools in Lappeenranta, one school in Vyborg and one school in Pervomayskoe. One of the Finnish schools was a foundation-owned state-supported comprehensive school specialised in teaching the Russian language, while the other schools were normal publicly funded comprehensive schools. The language school offered us one more comparative angle to the material, as we were able to study whether the maps of its pupils differed from the maps of the other participants. We also wanted to compare two age groups with each other and collected maps from younger $\left(4^{\text {th }}\right.$ and $5^{\text {th }}$ grade classes, children aged between 9 and 11$)$ and older $\left(8^{\text {th }}\right.$ and $9^{\text {th }}$ grade classes, children aged between 13 and 15) children. In addition, we were interested in the temporal dimension. To study whether contemporary social and political developments would be mirrored on the maps, we collected a second set of maps in 2016 and 2017 (Table 1).

In the beginning of the mental mapping sessions, we asked the participants (1) to draw and write on the maps what they thought about the Finnish-Russian borderland, what is on the Finnish and Russian sides and what it is like to live in the area. We also wanted the participants (2) to reflect on the border between Finland and Russia. In the event the participants were having difficulties with the exercise, we asked them to draw and write what they thought about Finland and Russia, that is, what these countries are like in their minds (without asking them to compare the countries). This was only an additional instruction because we wanted to avoid guiding the participants to think too much in terms of the nation states. If the exercise still seemed too difficult, we offered to help the participants with additional further questions. We also pointed out that this was not a school exercise, and there 
were no right or wrong answers. The participants were asked to work alone, but they could communicate with their classmates if they wished.

Mental mapping is often combined with questionnaires or interviews to find out about the participants' backgrounds and the reasoning behind their choices (Trell \& van Hoven 2010). We conducted short interviews with some of the participants in the second mapping phase, but the talks did not provide us with useful information for interpreting the maps. Consequently, we decided not to continue doing them. Our focus was on the perceptions of the border and the borderland and less on where these perceptions come from (see Rinne \& Kallio 2017 on sources of some Finnish young people's spatial conceptions). Therefore, we chose to focus on the mapping, which considering the abstract topic was also more suitable for the younger children than, for instance, essay writing and was more workable in terms of reaching a large audience than interviews or focus groups, which are popular methods in childhood and youth research (see White \& Green 2012).

The analysis phase consisted of three parts and included both qualitative and quantitative elements. The first part followed the qualitative content analysis (QCA) method that allowed us to systematically describe and organise the contents of the maps (see Schreier 2012). We began this part by coding the drawings into texts to analyse them together with the textual elements (for instance, if the participant drew a building looking like Vyborg Castle, we wrote 'Vyborg Castle'). We then developed a coding frame by grouping all the elements on the maps into ten thematic categories and calculating how many elements the participants placed on the Finnish and Russian sides of the border and on the borderline or its near vicinity. Because we found many similarities between the elements on the maps and earlier mental maps studies, we based the categorisation on both the elements and the grouping used in Gillespie's (2010) mental mapping study. ${ }^{4}$ The categories were as follows: (1) Persons and people (people mentioned by name or position and other mentions of people and population), (2) Natural environment, (3) Animals, (4) Landmarks (cities, regions, buildings, monuments etc.), (5) Paths (roads, arrows etc.), (6) Traffic, (7) Symbols and stereotypes, (8) Economics (companies, trademarks, products, references to the economic situation etc.), (9) Country and society (features related to what Finland or Russia is as a country or society) and (10) Culture (references to culture, language, sports, food and stimulants and media). We also indicated in separate categories what kinds of differences and similarities the participants drew between the Finnish and Russian sides. Although the coding frame quantified the elements on the children's maps, its development was qualitative as it was partly datadriven and required interpretation of the elements and their belonging into the thematic categories.

In the second part of the analysis, we studied the contents of the categories and examined what elements the participants used on their side and the neighbouring side of the borderland as well as on the border or its near vicinity. We paid attention both to the quantity of the elements and their meanings. At this point, we also analysed the results according to the participants' nationality, age, gender, school, place of residence and time of mapping. In the final phase, we examined the results of the two previous parts against the theoretical concepts and existing literature.

\section{Finnish and Russian children (de)constructing borders and creating socio-spatial distinctions in the borderland}

Most of the participants filled their maps with both text and drawings. While some of the participants had difficulties with the exercise and could only come up with one or two elements, most of the participants (68\%) drew between 10 and 30 elements. Both the Finnish and Russian participants drew slightly more elements on the Russian rather than on the Finnish side, while both left the border with considerably fewer elements. Many of the maps were visually impressive, which supports the view that one of the greatest strengths of mental mapping is the possibility it offers for the participants to express themselves in a creative manner (Trell \& van Hoven 2010). As there is not enough space in this paper to cover all the contents of the maps, we will describe the most popular categories on both sides of the border, the most popular elements placed on the border and the most popular elements for producing differences and similarities between the Finnish and Russian sides. To highlight one of the findings of the analysis - that of spatial socialisation (see Paasi 1996) in terms of the Finnish and Russian participants differing in their perceptions - we will present the results by comparing the 
Table 2. Map elements by category (percentage of total in each location, \%).

\begin{tabular}{|c|c|c|c|c|c|c|}
\hline & \multicolumn{3}{|c|}{ the Finnish participants } & \multicolumn{3}{|c|}{ the Russian participants } \\
\hline & the Finnish side & the Russian side & the border & the Finnish side & the Russian side & the border \\
\hline (1) Persons and people & 14 & 16 & 13 & 6 & 6 & 5 \\
\hline (2) Natural environment & 17 & 8 & 5 & 13 & 15 & 18 \\
\hline (3) Animals & 3 & 3 & 0 & 6 & 9 & 0 \\
\hline (4) Landmarks & 17 & 16 & 19 & 17 & 38 & 20 \\
\hline (5) Paths & 2 & 3 & 19 & 3 & 1 & 19 \\
\hline (6) Traffic & 1 & 5 & 11 & 3 & 1 & 11 \\
\hline (7) Symbols and stereotypes & 6 & 7 & 2 & 11 & 10 & 2 \\
\hline (8) Economics & 9 & 8 & 7 & 8 & 1 & 0 \\
\hline (9) Country and society & 15 & 17 & 13 & 22 & 12 & 25 \\
\hline (10) Culture & 16 & 17 & 11 & 11 & 7 & 0 \\
\hline Total & 100 & 100 & 100 & 100 & 100 & 100 \\
\hline
\end{tabular}

descriptions of the Finnish and Russian participants (Table 2). We will also include examples of individual maps and discuss briefly how age, place of residence and school influenced the perceptions of the participants. There were no great differences between girls and boys or between the maps collected before and after year 2014, and therefore these issues will not be addressed.

\section{The Finnish participants}

The Finnish participants generally viewed the Finnish side of the borderland in a positive light. Their descriptions of their 'own' side of the border were dominated by landmarks and elements of the natural environment and culture. They marked their home city Lappeenranta and other cities located near the border on their maps, and Helsinki in the South and Lapland in the North. They described the landscape by drawing their school, a sauna and detached houses on this side of the border. The participants also sketched trees, forests and lakes on their maps and very often mentioned the largest lake in Finland, Lake Saimaa, by which their home city is located. Many participants also referred to national narratives related to nature and noted, for example, that Finland is 'a land of a thousand lakes'. Among the collective narratives related to culture, Santa Claus was mentioned often, but ice hockey was by far the most popular element. The participants wrote ice hockey on the maps, included the name of the ice hockey team Saipa of their home city and referred to the Ice Hockey World Championships. The success of Finland in these games seemed to be an important matter for the children, as they pointed out how Finland won the Championships in 1995 and that the silver medal Finland received this year 'is not a shame'.

On the Russian side of the borderland, the Finnish participants drew much fewer natural elements than on the Finnish side. On the contrary, they described what Russia is like as a country and society and what they consider as part of the Russian culture. They often mentioned that Russia is a large country and that there are big cities there. The participants drew cars and roads and wrote that there are many people in Russia (according to some even too many). These together with descriptions of apartment buildings and the cities of Vyborg, St Petersburg and Moscow indicate that the Finnish participants constructed socio-spatial distinctions (van Houtum et al. 2005; Scott \& Sohn 2018) between the Finnish and Russian sides by considering Russia to be more urban than Finland. They also contrasted the two sides of the borderland by using many characterisations with a negative connotation on the Russian side. Among the most frequently given characterisations were 'a lot of poverty', 'money has power', 'dictatorship', 'dirty' and 'mafia'. Many participants wrote 'the Soviet Union' on their maps, which either means that Russia was previously the Soviet Union or that it still is, in which case they were being sarcastic and considered Russia a backward country. Some of the other 


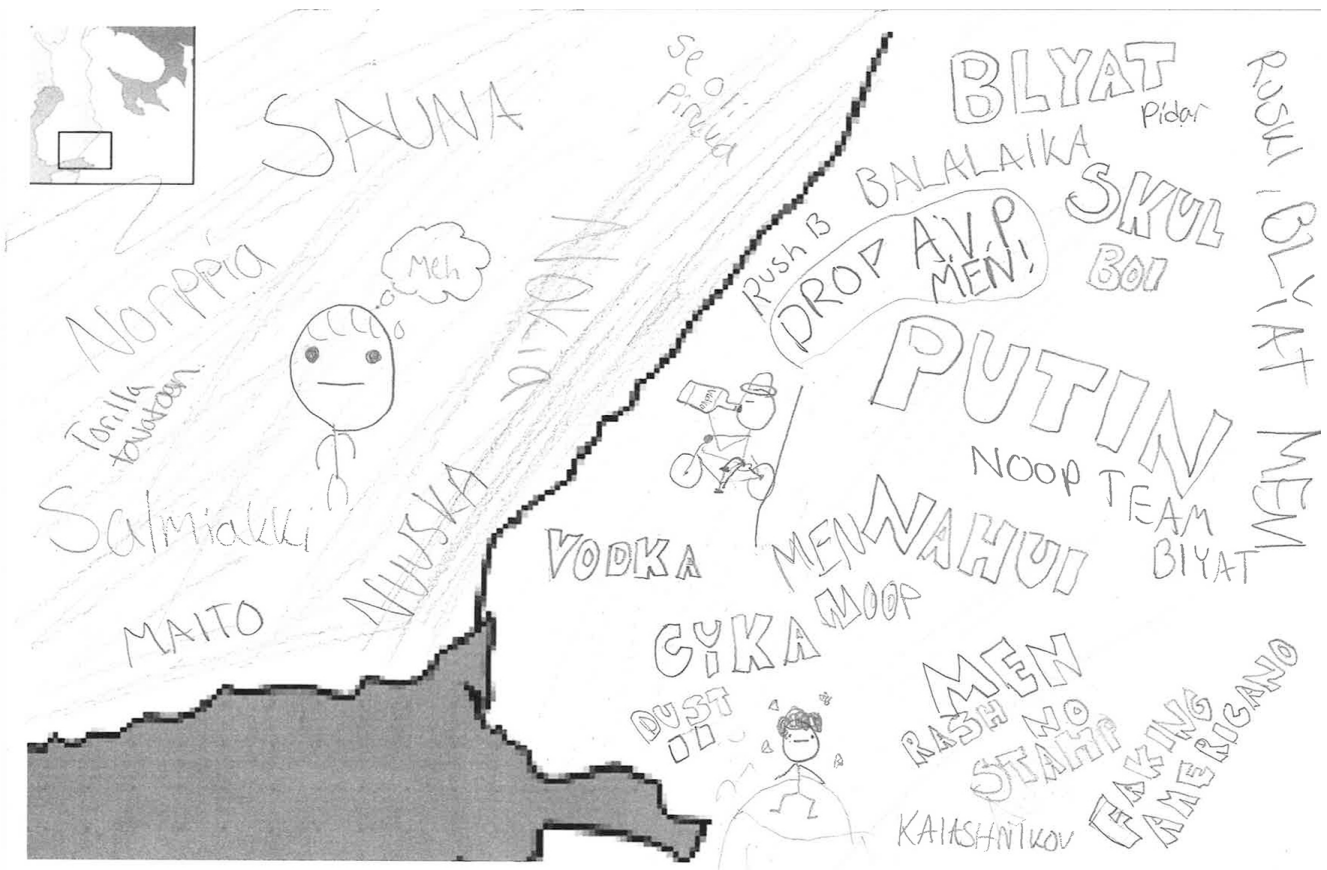

Fig. 1. Old and new stereotypes of Russia and Russians meet in the map drawn by an eighthclass boy from a normal Finnish school.

commonly mentioned elements carried a negative meaning for some and a positive meaning for others. Among these was President Vladimir Putin, who was the most popular person mentioned on the maps. He was referred to as 'Putin' or 'Vladimir'. On some maps he was accompanied by a smiley, whereas on others curse words were written beside his name. Ice hockey and Russia's Ice Hockey League KHL were other commonly mentioned elements that for some seemed to denote a similarity between Finland and Russia, while some pointed out that Russia is not as strong in ice hockey as Finland. The participants also named many different Russian foods, drinks and treats, including borscht soup, vodka and 'bubble chocolate'. While Russia is known for borscht soup and vodka around the world, the mentions of 'bubble chocolate' suggest the participants' own experiences of buying or receiving this chocolate from Russia. This indicates that the local and national scales interact in the children's perceptions of the borderland (see Scourfield et al. 2006).

The first map (Fig. 1) provides an example of this argument. Although being an extreme case, this map also demonstrates how negative many of the Finnish participants were in their descriptions of the Russian side and how they used the negative characterisations to construct borders (Scott 2015) between the Finnish and Russian sides. The map is drawn by an eighth-class boy from a normal Finnish school. He has written President Putin's name in the middle of the Russian side of the map. Some of the words he has written around the president's name are common Russian curse words, but some are unfamiliar even for a native Russian speaker. An online search reveals that these expressions are from an online video game, and many of the terms on the map are used for mocking Russian players for taking fatal risks and having poor teamwork skills. This illustrates how he uses new stereotypes of Russians alongside old stereotypes, such as balalaika and the Russian man in a fur hat in the lower part of the map, to convey meanings he attaches to Russia. The other figure riding the bike and drinking vodka from a bottle most probably does not represent a drunken Russian man but rather a local Finnish guy. Some Finnish people ride bikes to Russia, especially during weekends to drink cheap alcohol, and some young people start their evenings in Russian cafes and cycle back when 
the nightclubs open in Finland. In contrast to the Russian side, the Finnish side features things that many Finnish people are proud of, such as saunas, liquorice, Nokia and success in the Ice Hockey World Championships. The boy also mentions ringed seals that live only in Lake Saimaa but are used as a symbol of Finnish nature conservation and can act both as a symbol of locality and nationality.

Besides making socio-spatial distinctions by describing the two sides of the borderland in differing ways, the Finnish participants applied a large variety of elements to make direct comparisons between the Finnish and Russian sides of the border. They drew the Finnish flag and wrote 'Niinistö' (President of Finland), euro, Lutheran Church and Santa Claus on the Finnish side and drew the Russian flag and wrote 'Putin' (President of Russia), rouble, Orthodox Church and Ded Moroz (Russian Santa Claus) on the Russian side. They also constructed differences between the two sides of the borderland by attaching certain values to elements of nature, landscape and economy. The Finnish side was clean and 'eco', whereas the Russian side was dirty and 'not eco'. The houses on the Finnish side were said to be in good condition, while those in Russia were dilapidated. The participants also considered it to be expensive in Finland and cheap in Russia; one participant wrote that diesel costs 1.30 euro in Finland but just 75 cents in Russia.

In contrast to the differences, the Finnish participants drew considerably fewer parallels between the Finnish and Russian sides. The most popular element for constructing similarities and deconstructing the border was nature. The participants drew trees, forests and animals on both sides and mentioned that it is green both in Finland and Russia. Some of the similarities referred to the local life in the borderland and the participants' own experiences, as illustrated by the map drawn by a fifthclass Finnish girl from the school specialising in the Russian language (Fig. 2). She obviously has experience of travelling across the border because she sketched cars on the border and wrote 'Travelling is fun!' beside them. In addition, there are boats crossing the border, and she wrote

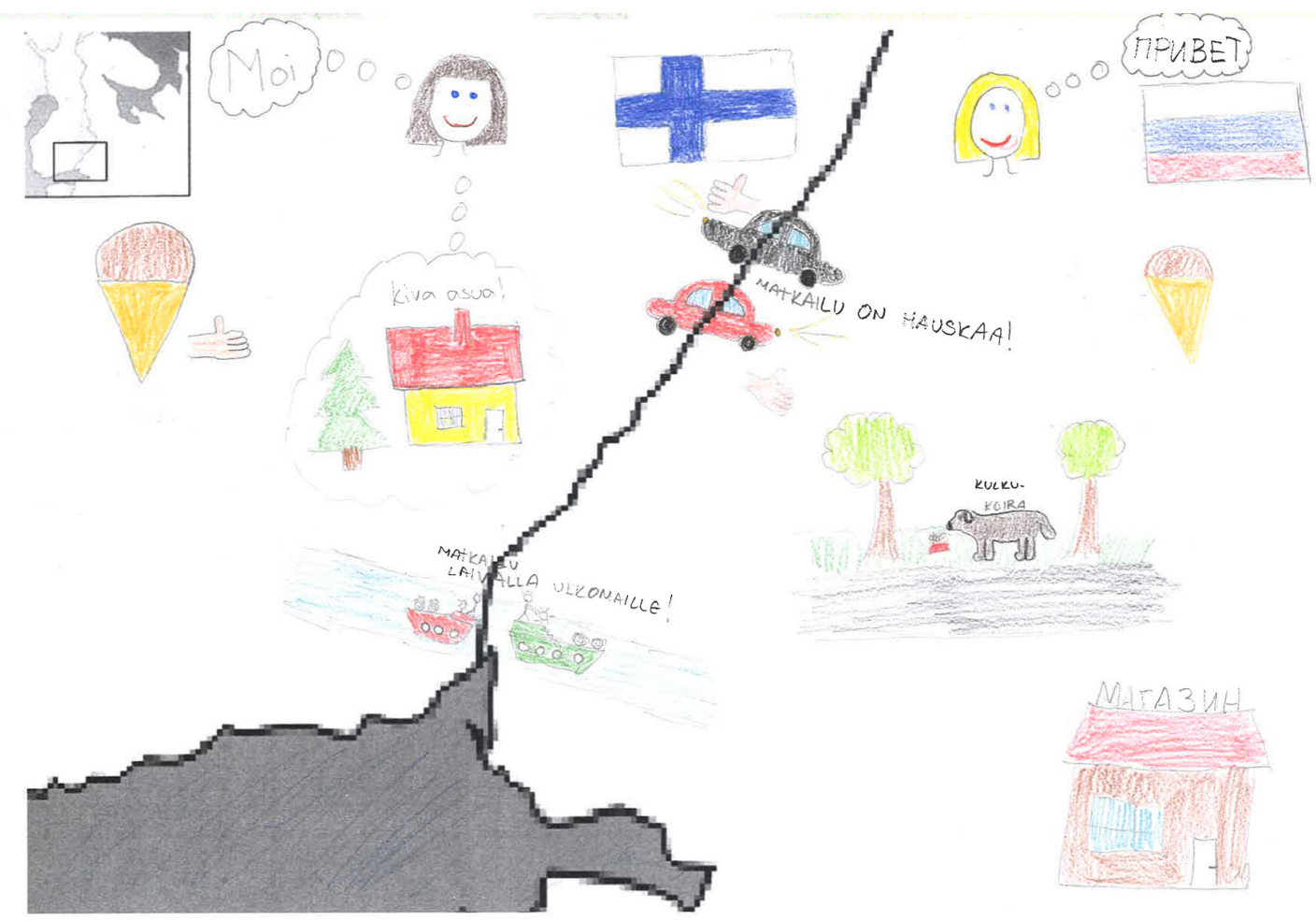

Fig. 2. A fifth-class Finnish girl from the school specialising in the Russian language draws a very positive image of the borderland and sees the border as a connecting element. 
'Travelling by boat abroad!' above them. For her, the landscapes in Finland and Russia are different, but there is ice cream and a girl of the same age in both countries. This map serves as a good example of two additional important results of the analysis. First, when compared to the map drawn by the Finnish eight-class boy (Fig. 1), it becomes obvious that the collective analysis underlines the relatedness of the children but overshadows the great variation between the maps and the individual children (Kallio 2014). In contrast to the general picture, this girl sees the border as a purely connecting element and the Russian side as lacking in negative features; even the stray dog has been fed. Second, the participants from the school specialising in the Russian language were generally less negative in their perceptions of the Russian side of the borderland than participants from the two other Finnish schools. This could be explained by the higher number of Russian migrants and Russian-speaking pupils in the participating classes but also by the fact that the participants in the language school study Russian and make regular field trips to Russia. They are, therefore, more familiar with Russia and Russian society, and more likely to base their perceptions on personal experiences than on secondary knowledge and existing stereotypes.

The Finnish participants included much fewer elements on the border or its near vicinity than on the Finnish and Russian sides of the map. Thus, it is obvious that the borderline between Finland and Russia played a less significant role for the participants as a physical state boundary than as a tool for ordering the space and making comparisons between the Finnish and Russian sides (van Houtum et al. 2005; Scott \& Sohn 2018). The participants most often represented the borderline as a place for border crossings, and drew customs and border checkpoints together with roads, railroads, arrows and traffic (cars, trains, tourist buses) crossing the border. The participants also pointed out that there are many Russians and Russian tourists on the Finnish side of the border and named shops that are popular among Russian cross-border shoppers. Besides these everyday characteristics related to border crossings, the participants used the border as a symbolic element. They referred to relations between Finland and Russia and between Finnish and Russian people by drawing shaking hands and 'hockey unites' signs or by writing swear words on the borderline. These either deconstructed the border by downplaying its significance or, on the contrary, underlined its meaning as a marker of the national territory (Scott 2015).

\section{The Russian participants}

The Russian participants were somewhat more critical of their 'own' side of the borderland but named Russia as their 'motherland' and referred to many features of national pride on their maps. Among these were famous Russian poets, writers and composers. The Russian participants depicted the Russian side with a remarkable number of landmarks - over one-third of all the elements were names of different cities, villages and sights. The participants most frequently mentioned (most of) their home city Vyborg and its famous sights, such as Vyborg Castle, Park Monrepo and Round Tower. The second most frequently mentioned city was St Petersburg, which is the closest large city and the capital of Leningrad oblast, the administrative region to which Vyborg belongs. St Petersburg was marked on the maps much more frequently than the capital of Russia, Moscow, and therefore it is clearly an important city for the children. As the Finnish participants, the Russian participants drew many elements of the natural environment on their 'own' side of the borderland. These were primarily trees, forests, lakes and rivers. At times, the Russian participants used trees as symbols and thereby referred to collective meanings attached to the natural elements. They, for instance, drew on the Russian side birch trees, which are commonly known as symbols of Russia and Russian nature. In addition, the apple trees that many of the Russian participants drew on their maps could be considered to have symbolic meaning alluding to 'home', as they were always drawn on the Russian side.

The forests, trees and water basins that the Russian participants drew on the Russian side continued to the Finnish side. By describing the Finnish side of the borderland with many natural elements, the participants deconstructed the border between the two sides of the borderland. However, many participants differentiated between the two sides by mentioning that the nature, water and air is cleaner in Finland than in Russia. The second most popular element that the Russian participants placed on the Finnish side were names of cities and other landmarks. The three most often mentioned 


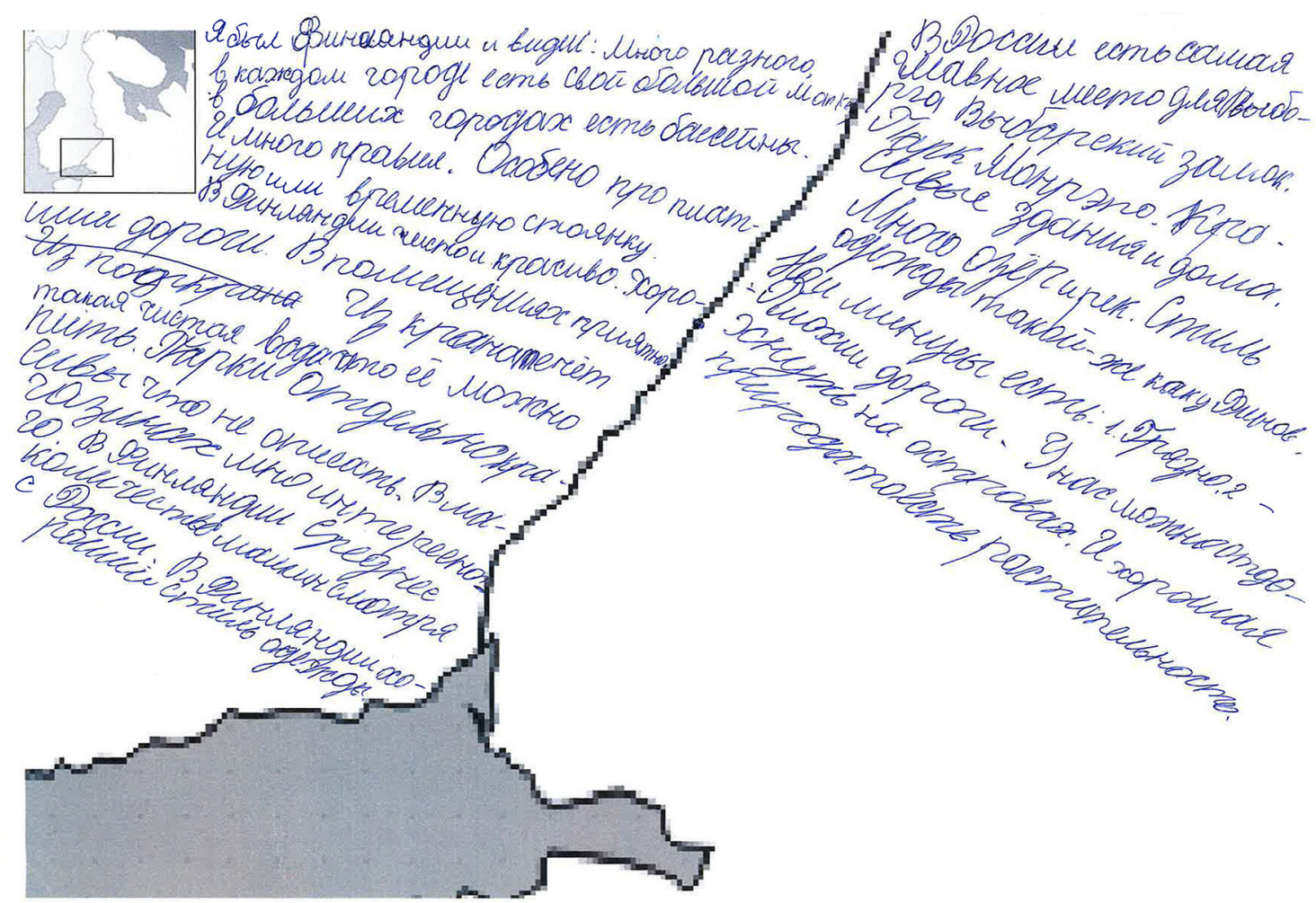

Fig. 3. Similarly to many of the younger participants, a fifth-class Russian boy describes his experiences in the Finnish-Russian borderland and writes about his travels to Finland on his map.

cities were Helsinki, Lappeenranta and Imatra. The appearance of the capital city of Helsinki on the maps was to be expected, but Lappeenranta and Imatra seemed to be very important geographic locations for the participants despite their smaller size. These border cities are important shopping destinations for Russian travellers, and consequently the participants surrounded them with the names of different shops. This indicates that the Russian participants have considerable experience in travelling to Finland, especially to its border cities.

These experiences influence their perceptions of the borderland and of Finland and Russia, as illustrated by the third map example (Fig. 3). On the map, a fifth-class Russian boy from Vyborg discusses his experiences in Finland in the following way:

A lot of different things; in each city there is a large park, in big cities there are swimming pools. And, a lot of rules, especially concerning parking fees or temporary parking. It is clean and beautiful in Finland. Good roads. It is nice inside of buildings. From the tap flows such clean water that it is possible to drink it. The parks are so beautiful that it is not possible to describe them. There are many interesting things in shops. In Finland, the number of cars is average compared to Russia. In Finland, there is a nice style of clothing.

This text shows that the boy knows many details about Finland, which are based on his own observations in the country. The boy's description of the Russian side mirrors his image of Finland, as he points out that it is dirty in Russia and the roads are bad. Yet at the same time, he praises Vyborg and its Castle and Park Monrepo and the rich nature in Russia. He also observes a clear resemblance between Finland and Russia, stating that the style of clothing is identical in both countries. The younger participants of the study were generally more likely to demonstrate their knowledge and experiences, while the older participants expressed their positions and attitudes on their maps (Fig. 1, 2) and made 
critical comments concerning their own locality and country as well. This points to the development of a person's relationship with their nation and locality in childhood (Scourfield et al. 2006; Barrett 2007).

Participants from Pervomayskoe school, which is located further away from the border, were not as familiar with the border area and Finland as were the participants from Vyborg. Many of the younger participants wrote on their maps that they have not been to Finland and do not know anything about it. The older participants were clearly more familiar with Finland and had been there, but their markings concentrated less on border cities and more on Pervomayskoe and the villages around it, indicating that instead of the borderland, these places form the most important geographical framework and socialisation context (Paasi 1996) for them.

Like the Finnish participants, the Russian participants included few elements on the border and used it mainly as a symbolic element and a tool for creating socio-spatial distinctions in the borderland (van Houtum et al. 2005; Scott \& Sohn 2018). All the elements that the Russian participants placed on the border (border crossing points, customs buildings, roads, railroads and gas pipelines) represent it as a place for border-crossings and can be considered connecting features between the two sides of the borderland. The participants constructed connections across the border also by writing on the border such statements as 'friends', 'friendship' and 'assisting each other'.

The Russian participants contrasted the two sides of the borderland by placing traditional symbols and references to Russian classical culture on the Russian side and markers of modern-day economy on the Finnish side. On the Russian side, the participants hardly mentioned anything related to economics, except for gas pipes and oil extraction on some maps. Our last example (Fig. 4) portrays this contrast very well. On the Russian side, an eight-class Russian girl from Vyborg sketched a ballerina

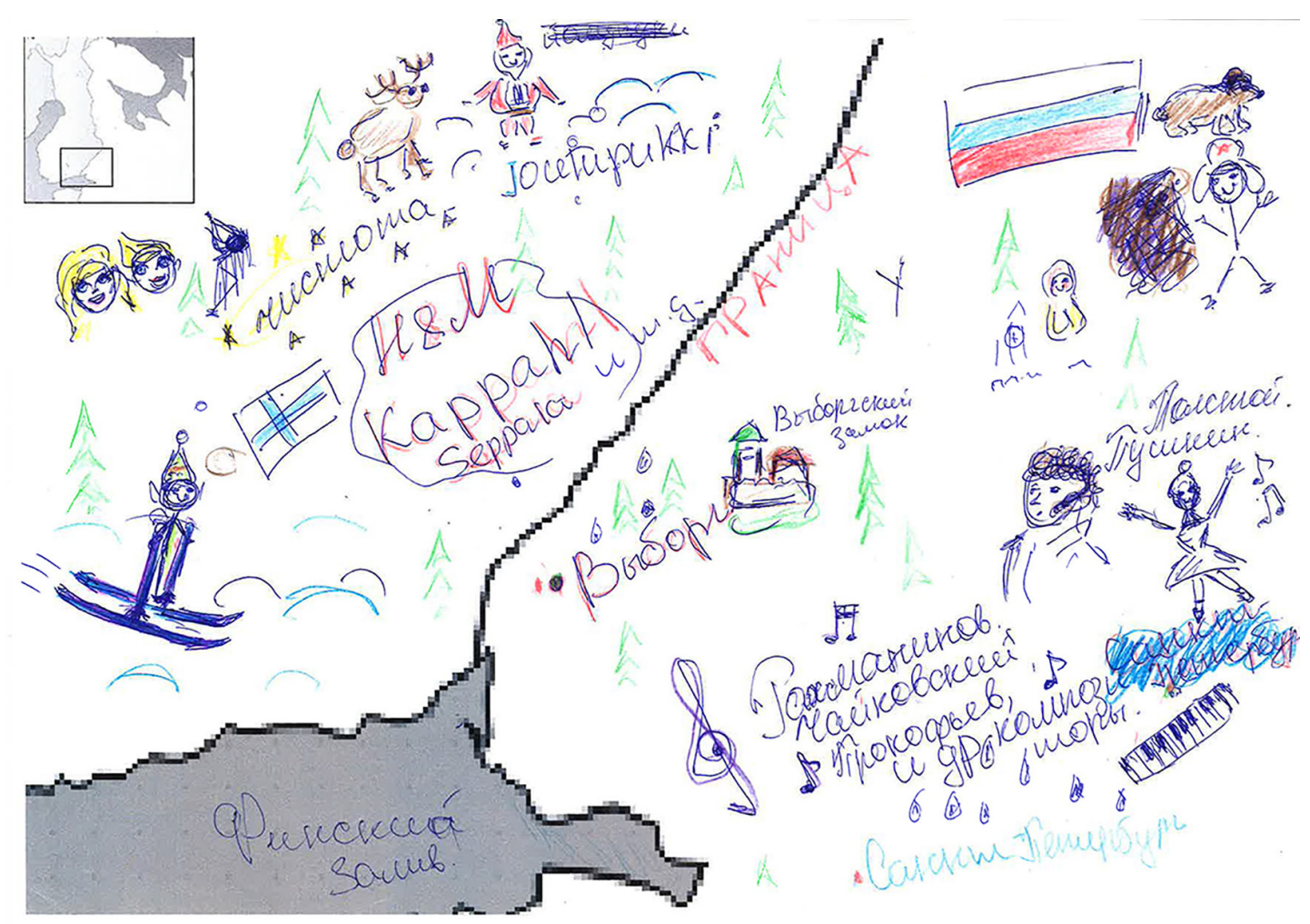

Fig. 4. An eight-class Russian girl uses traditional symbols and references to Russian classical culture to describe the Russian side of the border, but on the Finnish side she mentions (besides stereotypical images) clothing stores, which indicate her own experiences of shopping in Finnish border towns. 
together with the Russian national poet Aleksander Pushkin and wrote the names of famous Russian writers and composers, including Tolstoi, Rachmaninoff, Tchaikovsky and Prokofiev. She also decorated the Russian side with a Russian flag, Vyborg Castle and such traditional Russian symbols as the bear, a matryoshka and a man in a Soviet style fur hat. On the Finnish side, she included the Finnish flag and such stereotypical images as a reindeer, Santa Claus (with the Finnish name 'Joulupukki'), and a blond man and woman, but she also wrote the names of clothing stores, such as H\&M, KappAhl and Seppälä, which she has probably visited herself. This map again underlines the significance of the local experience, and how the local and national contexts interact in the processes of spatial socialisation (Paasi 1996).

In addition, the Russian participants contrasted the Finnish and Russian sides of the border by portraying different animals. These were not just any animals but rather species with a 'nationality', a symbolic meaning. On the Russian side, they drew bears and moose, and on the Finnish side they drew moose and reindeer but no bears. The bear was clearly a national symbol for them, and by using this symbol on their maps the participants reconstructed collective narratives related to their country and culture.

\section{Discussion}

This paper set out to study Finnish and Russian children's perceptions of the Finnish-Russian border and the borderland. It also aimed to examine the children's territorial identifications in the borderland. The above analysis of the mental maps illustrates that the more open border regime and the mobility across the Finnish-Russian border clearly impacts perceptions related to the border, as the children participating in this study most frequently represented it as a place for border crossings. However, the border continues to play an important role as a symbolic element and as a tool for bordering in terms of ordering space and constructing socio-spatial distinctions (van Houtum et al. 2005; Scott \& Sohn 2018). The participants of the study used a wide spectrum of elements ranging from the smallest food items to symbols and characterisations of societies and cultures to describe the Finnish and Russian sides of the border and to construct differences and similarities between them. The elements were based on personal knowledge, experiences and socially shared understandings and included feelings and ideas that the participants attach to Finland, Russia and their localities (Rose 1995; Gieseking 2013; Rinne \& Kallio 2017). This illustrates the complexity of the bordering processes that these children engage in and underlines their active role in the social life of the borderland (Spyrou \& Christou 2014).

In line with previous mental mapping studies, the participants' perceptions of the borderland are connected to the social and spatial contexts in which they live (see e.g. Gould 1973; Saarinen 1973; Gould \& White 1974; Gillespie 2010; Reynolds \& Vinterek 2016). On the one hand, the findings suggest national socialisation (Paasi 1996) and the importance of the national framework, as the Finnish and Russian participants differed in their perceptions of the borderland and the way in which they constructed differences and similarities in it. The Finnish participants constructed more differences than similarities between the Finnish and Russian sides of the border and considered the Russian side to be more urban and less attractive than the Finnish side. The Russian participants pictured the Russian side similar to the Finnish side, especially in terms of the natural environment. They contrasted the two sides of the border using traditional symbols and references to Russian classical culture on the Russian side and by drawing shops and modern Finnish trademarks on the Finnish side of the borderland.

This finding reflects previous studies about the image of Russia in Finland and the image of Finland in Russia. For Finland, Russia has been the 'other' country and culture in national identity building, and many stereotypical images of Russia and Russians have persisted up to the present time (Paasi 1996; Laine 2015). For Finnish children, Western (American and British) culture is more familiar and pursuable than the Russian culture because they see Russia mainly in news and in a very critical light (Rinne \& Kallio 2017). Recent studies have discovered, however, that the image of Russia is changing in Finland and stereotypical images have begun to erode at the level of everyday life (Laine 2015). Russians generally have a positive image of Finland (Kolossov 2003; Kangas 2015; Ministry for Foreign 
Affairs of Finland 2017), even if in cities and regions located close to the Finnish border, the image of Finland and Finns has been more multifaceted and included also controversial features (llyuha 2004). Russian typically associate Finland with natural beauty and perceive it as a rich country with a high standard of living, a good place for winter vacations and sports as well as a source of quality consumer goods (Kolossov 2003).

On the other hand, the Finnish and Russian participants share the local borderland context, which seems to play an important role in forming the perceptions of the locality and the neighbouring country. The participants described the observations of border-related phenomena and their own travelling experiences in the borderland. Similar to other border regions (e.g. Schack 2001; da Silva 2014), the action space of the Finnish and Russian children is asymmetrical; the Russian participants (especially those living closer to the border in Vyborg) travel across the border more often, while the Finnish participants observe cross-border phenomena on their side of the border. The participants with more experience of interacting with Finnish/Russian people and travelling to Finland/Russia seemed to have a more positive perception of the other country and culture. For example, the participants attending the school specialising in Russian language were less negative in their perceptions of the Russian side of the borderland compared to the participants from the two other Finnish schools. However, as the analysis illustrates, local encounters are not a one-way street to perceiving 'the other' in a more positive manner; rather, they enable more nuanced ways of seeing 'the other' and 'the self' (Ahponen 2011; Christou \& Spyrou 2017).

The analysis further shows that the participating children's perceptions of the borderland vary widely between individuals. Thus, among the participants we find nationally and locally related but independently thinking and acting subjects (Kallio 2014). The mental maps suggest that these children experience an increasingly transnational Finnish-Russian borderland, which is turning into 'an incubator of multiple identities' (Spyrou \& Christou 2014, 13), offering the children more possibilities for negotiating their territorial and other identities. As a standalone material, the maps did not allow examining how the children narrate and construct their identities in the borderland and whether the border and the 'other side' is (becoming) a central part of some of the children's identities (for such accounts, see da Silva 2014; Christou \& Spyrou 2017). Further, it was not possible to determine how exactly a child's bordering processes are related to his or her identity construction in terms of separating between 'our' and the 'other' side of the border and the 'self' and the 'other' (Sibley 1995; Newman 2003).

Nevertheless, the borderland scale mental maps illuminate certain fundamental aspects related to children's territorial identifications. Consistent with the literature on children's national and local identification (e.g. Barrett 2007; van der Burgt 2008), most participants viewed their side of the border in a positive light. However, the older participants were more inclined to include their positions and attitudes on their maps and to make critical comments concerning their own locality and country. This supports the view that a person's identification towards one's nation and the locality proceeds from highly positive to more informed and objective over time (Nugent 1994; Barrett 2007). This is related to a child's cognitive development but also to the social and cultural nature of child development and a child's ability to view one's country or place of residence from the perspective of others (Scourfield et al. 2006).

The participants also used many landmarks and features of the natural environment on their side of the border. Kaplan and Herb (1999) point out how elements or characteristics contained within a territory are crucial constituents of the definition and identification of a group living within it. The natural environment has a special significance in national discourse and identity, and it is used to emphasise the unique character of a nation (Herb 1999). The participants of the study used natural elements (sometimes with specific symbolic meanings) to highlight the specificities of their national territory. Among other things, the Finnish participants talked about 'a land of a thousand lakes', which is fundamental to the Finnish national narrative (Paasi 1996), and the Russian participants referred to Russia's vastness and the richness of nature, which have endured in the Russian national narrative (Silova et al. 2014). In doing this and in referring to other important collective narratives, such as achievements in the fields of sports and culture, they drew from shared cultural resources that are essential for feeling like part of a nation (Scourfield et al. 2006; Habashi \& Worley 2009). Even so, the nation identification of the participants was closely intertwined with their local place identification 
(Scourfield et al. 2006). Thus, it is possible to argue that local border-related phenomena and children's border-crossing experiences are increasingly relevant for children's national and local identification processes in the Finnish-Russian borderland.

\section{Conclusion}

Research on children living in different borderlands of the world is only beginning to develop. Existing studies have underlined the role of children as active participants in borderlands and bordering processes (Spyrou \& Christou 2014; Venken 2017). This study suggests that Finnish and Russian children living in close vicinity to the Finnish-Russian border play an important part in the social life of the borderland by taking an active role in the bordering processes in their communities (van Houtum et al. 2005; Scott 2015). By illustrating with children's mental maps how these processes are connected to spatial socialisation (Paasi 1996; Kallio 2014) and the national and local contexts that the children live in, this work makes three important contributions. The first one is empirical, as it provides novel information regarding children's perceptions and identifications in the Finnish-Russian borderland. The second one is methodological, as it adjusts the mental mapping method to a borderland context and thus allows similar studies to be undertaken in other border areas. The third contribution of the study is theoretical, as it enhances our understanding of the complexity of the bordering processes occurring in borderlands.

Further research should be conducted with adults and senior citizens to explore intergenerational differences in perceptions and identifications. Mental maps collected from other borderlands would also enrich our understanding of borders in children's lives and the role of children in borderlands and bordering processes.

\section{Notes}

1 In this article, we address the participants of the study as 'children'. The older participants could also be called 'young people', but for the text to be more reader friendly, we only refer to 'children'.

2 The problem with the blank paper was that it left some of the participants with no idea regarding what to draw or write on the paper, as the borderland was too abstract an area to visualise in the form of a map. On the maps with borders and water basins, on the other hand, the participants were not able to draw and write freely and many ended up adding names of cities and places they knew.

${ }^{3} \mathrm{~A}$ portion of the maps (69) were collected by schoolchildren taking part in the 'Cross-Border Citizen Scientists' project. This project was organised in the Finnish-Russian borderland in 2012-2013 and funded by the South-East Finland - Russia ENPI CBC 2007-2013 programme. The aim was to train a group of Finnish and Russian schoolchildren (12-13 years old at the beginning of the project) to become experts of their own cross-border area. In the spirit of the 'citizen science' concept, they studied the cross-border area by collecting materials and conducting small research projects.

${ }^{4}$ Gillespie's (2010) scheme utilised, among others, Lynch's (1960) classification rubrics and divided the map elements into designative and appraisive categories. The designative categories included spatial elements (Landmarks, Paths, Edges, Districts and Social elements), and the appraisive categories included imagery that illustrated the children's feelings regarding their neighbourhood (Function, Recreation, Nature, Transportation, Person and Animal).

\section{Acknowledgements}

We express our gratitude to the teachers and school directors that enabled us to collect the mental maps in the participating schools. We thank all the participants that drew the maps and made our work such a fascinating experience. We are grateful for Heikki Eskelinen and Jarmo Kortelainen for their support and the comments that they provided for earlier versions of this paper as well as the two anonymous reviewers for their valuable feedback in revising the paper. We would like to express our deepest appreciation to Western Social Science Association for rewarding an earlier version of this paper an Honourable Mention in the 2018 Student Paper Competition. A part of the maps was 
collected in the 'Cross-Border Citizen Scientists' project, which was financially supported by the South-

East Finland-Russia ENPI CBC 2007-2013 programme, project no. SE425.

\section{References}

Ahponen, P. (2011) Miserable or golden Karelia? Interpreting a cross-border excursion of students from Finland to Russia. Journal of Borderlands Studies 26(2) 145-159. https://doi.org/10.1080/0886 5655.2011.641324

Anderson, B. (1983) Imagined Communities: Reflections on the Origin and Spread of Nationalism. Verso, London.

Barrett, M. D. (2007) Children's Knowledge, Beliefs and Feelings about Nations and National Groups. Psychology Press, Hove.

Billig, M. (1995) Banal Nationalism. Sage, London.

van der Burgt, D. (2008) How children place themselves and others in local space. Geografiska Annaler: Series B, Human Geography 90(3) 257-269. https://doi.org/10.1111/j.1468-0467.2008.291.x

Christou, M. \& Spyrou, S. (2017) The hyphen in between: children's intersectional understandings of national identities. Children's Geographies 15(1) 51-64. https://doi.org/10.1080/14733285.2016.12 25000

Cieslik, M. \& Simpson, D. (2013) Key Concepts in Youth Studies. Sage, London. https://doi. org/10.4135/9781526401694

Gieseking, J. J. (2013) Where we go from here: the mental sketch mapping method and its analytic components. Qualitative Inquiry 19(9) 712-724. https://doi.org/10.1177/1077800413500926

Gieseking, J. J., Mangold, W., Katz, C., Low, S. \& Saegert, S. (2014) The People, Place, and Space Reader. [Bookshelf Online] https://online.vitalsource.com/\#/books/9781317811879/

Gillespie, C. A. (2010) How culture constructs our sense of neighborhood: mental maps and children's perceptions of place. Journal of Geography 109(1) 18-29. https://doi. org/10.1080/00221340903459447

Gould, P. R. (1973) On mental maps. In Downs, R. M. \& Stea, D. (eds.) Image and Environment: Cognitive Mapping and Spatial Behaviour, 182-220. Arnold, London.

Gould, P. \&White, R. (1974) Mental Maps. Routledge, London. https://doi.org/10.4324/9780203163757

Habashi, J. \& Worley, J. (2009) Child geopolitical agency: a mixed methods case study. Journal of Mixed Methods Research 3(1) 42-64. https://doi.org/10.1177/1558689808326120

Hart, R. A. \& Moore, G. T. (1973) The development of spatial cognition: a review. In Downs, R. M. \& Stea, D. (eds.) Image and Environment: Cognitive Mapping and Spatial Behaviour, 246-288. Arnold, London.

Herb, G. H. (1999) National identity and territory. In Kaplan, D. H. \& Herb, G. H. (eds.) Nested Identities. Nationalism, Territory, and Scale, 9-30. Rowman \& Littelfield, Lanham, MD.

Holloway, S. L. \& Valentine, G. (2004) Children's geographies and the new social studies of childhood. In Holloway, S. L. \& Valentine, G. (eds.) Children's Geographies. Playing, Living, Learning, 1-28. Routledge, London. https://doi.org/10.4324/9780203017524

van Houtum, H., Kramsch, O. \& Zierhofer, W. (2005) Prologue. B/ordering space. In Van Houtum, H., Kramsch, O. \& Zierhofer, W. (eds.) B/ordering Space, 1-13. Ashgate, Burlington, VT.

Ilyuha, O. P. (2004) Menyayushchiysya obraz soseda: Finlyandiya i finny v predstavleniyah zhiteley Kostomukshi. In Tsamutali, A. N., Ilyuha, O. P. \& Kovalenko, G. M. (eds.) Mnogolikaya Finlyandiya. Obraz Finlyandii i finnov v Rossii, 358-374. Novgorod State University, Velikiy Novgorod.

Jukarainen, P. (2001) Rauhan ja raudan rajoilla. Nuorten maailmanjäsennyksiä Suomen ja Venäjän sekä Ruotsin ja Suomen rajojen tuntumassa. Like, Helsinki.

Kallio, K. P. (2014) Rethinking spatial socialisation as a dynamic and relational process of political becoming. Global Studies of Childhood 4(3) 210-223. https://doi.org/10.2304/gsch.2014.4.3.210

Kangas, M. (2015) Predstavlenie rossiyskih studentov o finnah i Finlyandii - na osnove oprosa. Master's thesis in Russian language and culture. Department of Languages, University of Jyväskylä. jyx. jyu.fi/bitstream/handle/123456789/48122/URN_NBN_fi_jyu-201512154047. pdf? sequence $=5$ \&isAllowed $=y$

Kaplan, D. H. \& Herb, G. H. (1999) Introduction: a question of identity. In Kaplan, D. H. \& Herb, G. H. (eds.) Nested Identities. Nationalism, Territory, and Scale, 1-6. Rowman \& Littelfield, Lanham, MD.

Kolossov, V. (2003) 'High' and 'low' geopolitics: images of foreign countries in the eyes of Russian citizens. Geopolitics 8(1) 121-148. https://doi.org/10.1080/714001015 
Laine, J. (2015) No news is good news? Making the Finnish public image of Russia. GeoJournal 80(1) 93-112. https://doi.org/10.1007/s10708-014-9539-9

Lynch, K. (1960) The Image of the City. The MIT Press, Cambridge (MA) and London.

Martinez, O. (1994) Border People: Life and Society in the U.S.-Mexico Borderlands. University of Arizona Press, Tucson.

McKnight, M. \& Leonard, M. (2014) Bordering in transition: young people's experiences in 'postconflict' Belfast. In Spyrou, S. \& Christou, M. (eds.) Children and Borders, 164-179. Palgrave Macmillan, Houndmills, Basingstoke and Hampshire. https://doi.org/10.1057/9781137326317

Ministry for Foreign Affairs of Finland (2017). Russians have a positive attitude towards Finland. Press Release 19.9.2017 < www. finland.or.jp/public/default.aspx? contentid=366541\&nodeid $=41267 \& \mathrm{c}$ ontentlan=2\&culture $=$ en-US>. 2.4.2018.

Newman, D. (2003) On borders and power: a theoretical framework. Journal of Borderlands Studies 18(1) 13-25. https://doi.org/10.1080/08865655.2003.9695598

Nugent, K. J. (1994) The development of children's relationships with their country. Children's Environments 11(4) 281-291.

Paasi, A. (1996) Territories, Boundaries and Consciousness: The Changing Geographies of the FinnishRussian Border. John Wiley, Chichester.

Popescu, G. (2012) Bordering and Ordering the Twenty-First Century: Understanding Borders. Rowman \& Littlefield, Lanham, MD.

Prokkola, E-K. (2008) Making bridges, removing barriers: cross-border cooperation, regionalization and identity at the Finnish-Swedish border. Nordia Geographical Publications 37(3). University of Oulu, Oulu.

Qvortrup, J., Corsaro, W. A. \& Honig, M-S. (2016) Why social studies of childhood? An introduction to the handbook. In Qvortrup, J., Corsaro, W. A. \& Honig, M-S. (eds.) The Palgrave Handbook of Childhood Studies, 1-18. Palgrave Macmillan, Basingstoke.

Reynolds, R. \& Vinterek, M. (2016) Geographical locational knowledge as an indicator of children's views of the world: research from Sweden and Australia. International Research in Geographical and Environmental Education 25(1) 68-83. https://doi.org/10.1080/10382046.2015.1106205

Rinne, E. \& Kallio, K. (2017) Nuorten tilallisten mielikuvien lähteillä. Alue ja ympäristö 46(1) 17-31. https://aluejaymparisto.journal.fi/article/view/64904

Rose, G. (1995) Place and identity: a sense of place. In Massey, D. \& Jess, P. (eds.) A Place in the World?: Places, Cultures and Globalization (The Shape of the World: Explorations in Human Geography), 87132. The Open University, London.

Rumford, C. (2008) Introduction: citizens and borderwork in Europe. Space and Polity 12(1) 1-12. https://doi.org/10.1080/13562570801969333

Saarinen, T. (1973) Student views of the world. In Downs, R. M. \& Stea, D. (eds.) Image and Environment: Cognitive Mapping and Spatial Behaviour, 148-161. Arnold, London.

Schack, M. (2001) Regional identity in border regions: the difference borders make. Journal of Borderlands Studies (16)2 99-114. https://doi.org/10.1080/08865655.2001.9695576

Scholz, G. (2011) Der SaarLorLux-Raum - zwischen Realität, Illusion und Vision. PhD dissertation. Department of Geography, University of Trier. <https://ubt.opus.hbz-nrw.delopus45-ubtrl frontdoor/deliver/index/docld/426/file/Dissertation_Gundula_Scholz.pdf $>$

Schreier, M. (2012) Qualitative Content Analysis in Practice. Sage Publications, Los Angeles.

Scott, J. W. (2015) Bordering, border politics and cross-border cooperation in Europe. In Celata, F. \& Coletti, R. (eds.) Neighbourhood Policy and the Construction of the European External Borders, 27-44. Springer, Cham. https://doi.org/10.1007/978-3-319-18452-4_2

Scott, J. W. \& Sohn, C. (2018) Place-making and the bordering of urban space: interpreting the emergence of new neighbourhoods in Berlin and Budapest. European Urban and Regional Studies. https://doi.org/10.1177/0969776418764577

Scourfield, J., Dicks, B., Drakeford, M. \& Davies, A. (2006) Children, Place and Identity. Nation and Identity in Middle Childhood. Routledge, Abingdon. https://doi.org/10.4324/9780203696835

Sibley, D. (1995) Geographies of Exclusion: Society and Difference in the West. Routledge, London and New York.

Silova, I., Mead Yaqub, M., Mun, O. \& Palandjian, G. (2014) Pedagogies of space: (re)imagining nation and childhood in post-Soviet states. Global Studies of Childhood 4(3) 195-209. https://doi. org/10.2304/gsch.2014.4.3.195 
da Silva, S. M. (2014) Growing up in a Portuguese borderland. In Spyrou, S. \& Christou, M. (eds.) Children and Borders, 62-77. Palgrave Macmillan, Houndmills, Basingstoke and Hampshire. https://doi.org/10.1057/9781137326317

Spyrou, S. \& Christou, M. (2014) Introduction. In Spyrou, S. \& Christou, M. (eds.) Children and Borders, 1-23. Palgrave Macmillan, Houndmills, Basingstoke and Hampshire. https://doi. org/10.1057/9781137326317

Stea, D. \& Blaut, J. M. (1973) Some preliminary observations on spatial learning in school children. In Downs, R. M. \& Stea, D. (eds.) Image and Environment: Cognitive Mapping and Spatial Behaviour, 226-234. Arnold, London.

Strüver, A. (2005) Stories of the 'Boring Border': The Dutch German Borderscape in People's Minds. LIT Verlag, Münster.

Trell, E-M. \& van Hoven, B. (2010) Making sense of place: exploring creative and (inter)active research methods with young people. Fennia 188(1) 91-104. https://fennia.journal.fi/article/view/2522

Venken, M. (2017) Introduction: borderland studies meets child studies. A European encounter. In Venken, M. (ed.) Borderland Studies Meets Child Studies. A European Encounter, 11-41. Peter Lang, Frankfurt am Main. https://doi.org/10.3726/b11559

White, R. J. \& Green, A. E. (2012) The use of mental maps in youth research: some evidence from research exploring young people's awareness of and attachment to place. In Heath, S. \& Walker, C. (eds.) Innovations in Youth Research, 58-78. Palgrave Macmillan, Houndmills, Basingstoke and Hampshire. https://doi.org/10.1057/9780230355880

Wilson, T. M. \& Donnan, H. (2012) Borders and border studies. In Wilson, T. M. \& Donnan, H. (eds.) A Companion to Border Studies, 1-25. Wiley-Blackwell, Chichester. https://doi. org/10.1002/9781118255223.ch1 